\title{
e-Governance for Municipal Hospitals: Subsidy Vs Quality of Healthcare Services
}

\author{
KV Ramani \\ Indian Institute of Management, \\ Ahmedabad, India
}

\author{
TS Lakhia \\ NHL Medical College, \\ Ahmedabad, India
}

ramani@imahd.ernet.in

\begin{abstract}
Ahmedabad Municipal Corporation (AMC) in the state of Gujarat, India looks after the basic needs of its four million citizens. AMC offers primary, secondary, and tertiary healthcare services at subsidized rates. The load on AMC tertiary healthcare hospitals has been increasing rapidly, stretching the hospital resources beyond limits. Insufficient resources at these hospitals call for increased allocation of AMC funds to provide a satisfactory level of service. However, AMC is unable to allocate a larger share of its finances to the health sector owing to similar demand from other sectors. AMC authorities are therefore concerned about their ability to offer quality healthcare services at subsidized rates. In this paper, we describe a few e-Gov. applications to address and resolve the issues related to costs, revenues, subsidy, and the quality of services, so that AMC can meet its social obligations in the health sector satisfactorily. Some of our recommendations have been already implemented, while others are under consideration.
\end{abstract}

\section{Introduction}

Ahmedabad Municipal Corporation (AMC) in the state of Gujarat, India looks after the basic needs of its four million citizens, spread over an area of 200 sq. kilometers. Geographically, AMC is divided into 43 wards that elect a total of 129 councilors, who in turn elect a Mayor. Mayor is the Chairman of AMC Board, which takes all policy decisions. The mayor is assisted by three statutory committees and thirteen sub-committees. The Municipal Commissioner, who is a civil servant from the Indian Administrative Service, is responsible for executing all the decisions taken by the AMC Board.

Healthcare is an area of considerable significance to AMC authorities. AMC allocates about 12-15 percent of its annual budget for the healthcare sector, and subsidizes the cost of healthcare to its citizens. Primary healthcare services are offered through 37 Family Welfare Centers, which focus on the problems related to child birth, malnutrition, water borne and air borne diseases etc. Secondary healthcare services are offered through 26 Municipal Dispensaries, 13 Maternity Homes and 5 Referral Hospitals, which offer basic outpatient services and limited inpatient services besides maternity and gynecology services. Tertiary healthcare services are offered through three large General Hospitals, and an Eye Care Hospital.

These general hospitals offer a wide range of outpatient and inpatient services, including a few super specialty services and also serve as teaching hospitals for undergraduate and postgraduate studies in medicine

Material published as part of these proceedings, either on-line or in print, is copyrighted by Informing Science. Permission to make digital or paper copy of part or all of these works for personal or classroom use is granted without fee provided that the copies are not made or distributed for profit or commercial advantage AND that copies 1) bear this notice in full and 2) give the full citation on the first page. It is permissible to abstract these works so long as credit is given. To copy in all other cases or to republish or to post on a server or to redistribute to lists requires specific permission from the publisher at Publisher@intormingsclence.org and nursing.

In this paper, we describe our work on egovernance of AMC tertiary healthcare hospitals, namely VS General Hospital (1200 beds), LG General Hospital (450 beds), SCL general Hospital (470 beds) and Nagri Eye Care Hospital (100 beds). 


\section{A Framework for e -Governance}

In this section we describe a framework for the e-governance of AMC hospitals. Central to our framework is an understanding of the parameters for governance of AMC hospitals.

We begin our discussions by analyzing the existing organizational structure of AMC for delivering tertiary healthcare services to its citizens. The municipal commissioner who heads the executive wing of AMC is assisted by nine deputy municipal commissioners (Dy MC). Dy MCs of finance, administration, engineering, and security assist the municipal commissioner on general administration. Dy MCs of East, West, Central, North, and South zones are responsible for all the activities in their wards, such as tax collection, delivery of municipal services, redressal of grievances, and so on. Each of these zonal Dy MCs

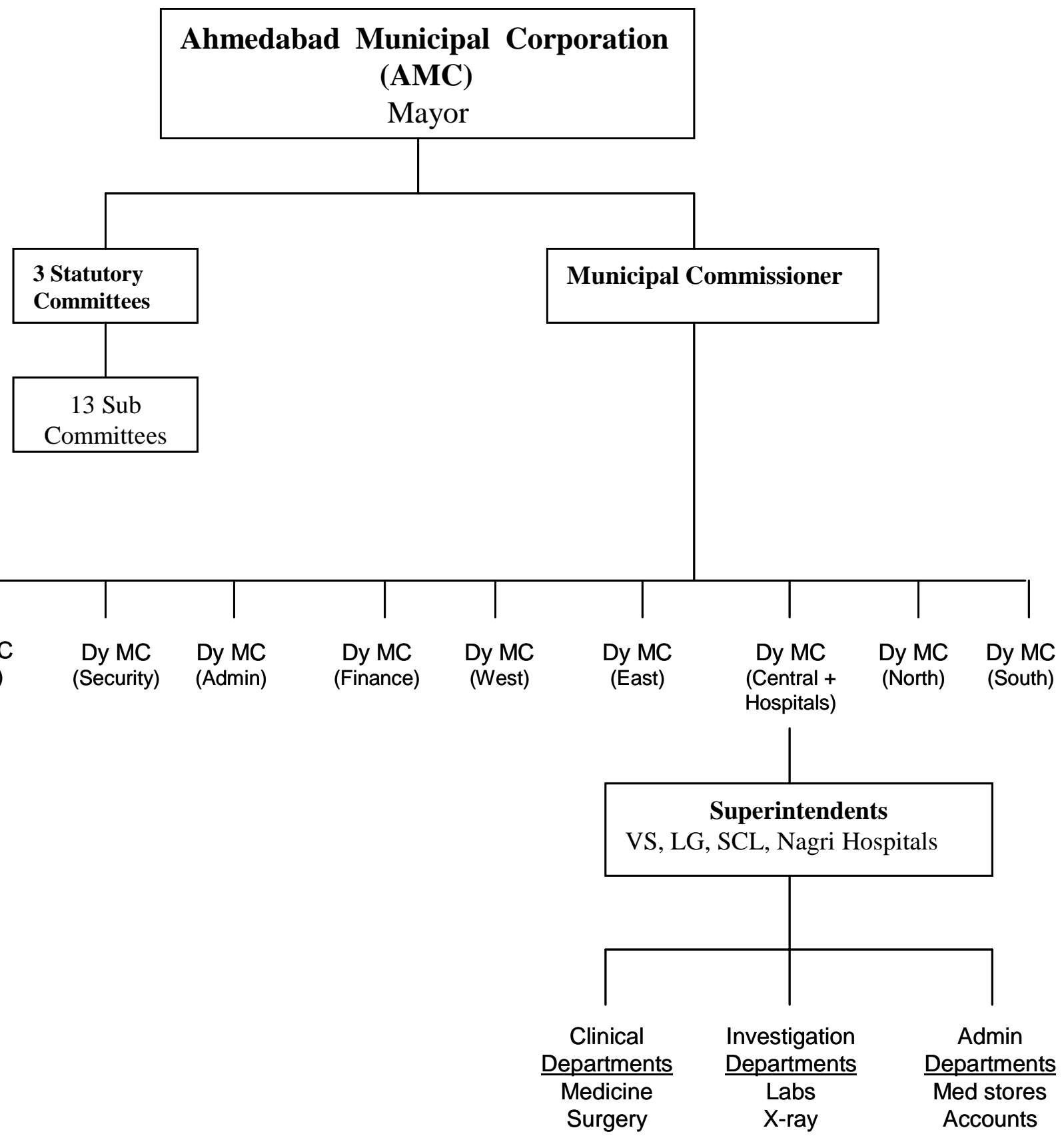

Figure 1: AMC Hospital Governance 
also holds an additional portfolio. The Dy MC (Central) holds the hospital portfolio, and is also called the Dy MC (Hospitals). The superintendents of AMC hospitals report to the Dy MC (Hospitals) who interacts with the Dy MCs of finance, administration, engineering, and security to provide the necessary administrative support to the hospitals. Each hospital is organized into several clinical, investigation, and administrative departments. The clinical departments, such as medicine and surgery, deliver healthcare services. Investigation departments such as laboratories and imaging departments assist the clinicians in the process of diagnosis. Administrative departments such as medical stores, finance and accounts departments provide the necessary support to the delivery of healthcare services. The organizational structure for governance of AMC hospitals is given in Figure 1.

With an understanding of the administrative structure for providing healthcare services, we are now in a position to understand the working of these hospitals. A summary of our observations on the working of AMC hospitals is given in Table 1, some of these are explained in detail below.

\section{Load on the tertiary care hospitals}

The combined load on the tertiary care hospitals has gone up by almost $35 \%$ in the last five years. The combined load handled by these hospitals in the year 1999-2000 amounted to1.2 million OPD cases, 120,000 indoor cases, 60,000 surgeries and 3 million investigations. However, there has been no augmentation of infrastructure and other resources in these hospitals to handle the increased number of patients satisfactorily.

\section{Revenue Expenses}

Fixed expenses accounts for almost $80 \%$ of the total revenue expenses, leaving insufficient funds to meet the variable expenses. Shortage of funds for variable expenses severely constraints the purchase of hospital supplies (consumables and disposables) and the spare parts for maintenance of medical equipments and instruments. Shortage of hospital supplies and long downtime of medical instruments and equipments force the patients to rely on private chemists and laboratories to meet their healthcare needs at higher costs. Unable to provide healthcare services, AMC hospitals end up generating big business for the private healthcare service providers.

\section{Revenue income from Patient care}

While the load handled by the hospitals has gone up significantly in the last few years, revenue from patient care has increased only marginally due to various reasons. One of the reasons is that AMC has not revised the service charges for healthcare services for the last 15 years while the input costs for services have gone up significantly during this period. Another reason is that many patients enjoy free treatment and/or additional subsidy on the already subsidized rates by producing "Low Income Certificate" from the AMC Councilors and other elected representatives.

\section{Capital Expenses}

Allocation of capital expensed has been very irregular and insufficient over the last few years due to financial constraints. As a result, AMC hospitals have not been able to replace their aged equipments and instruments in the operating theatres and investigation departments, adding to their concern in delivering hospital services. 


\begin{tabular}{|c|c|}
\hline $\begin{array}{l}\text { OBSERVATIONS ON THE WORKING OF AMC } \\
\text { HOSPITALS }\end{array}$ & $\begin{array}{l}\text { IMPLICATIONS ON COSTS, REVENUES, SUB- } \\
\text { SIDY, AND QUALITY }\end{array}$ \\
\hline $\begin{array}{l}\text { Patient load increased by almost } 30 \% \text { in the last } \\
5 \text { years. }\end{array}$ & $\begin{array}{l}\text { Hospital resources are stretched beyond limits to } \\
\text { offer services }\end{array}$ \\
\hline $\begin{array}{l}\text { AMC funds are limited, allocation for healthcare } \\
\text { sector insufficient. }\end{array}$ & $\begin{array}{l}\text { Unable to offer quality healthcare services at sub- } \\
\text { sidized rates. }\end{array}$ \\
\hline $\begin{array}{l}\text { Fixed expenses account for almost } 80 \% \text { of the } \\
\text { total revenue expenses }\end{array}$ & Not enough money left for variable expenses. \\
\hline $\begin{array}{l}\text { Variable expenses grossly inadequate for pur- } \\
\text { chase of hospital supplies (consumables and dis- } \\
\text { posables) and spare parts for the maintenance of } \\
\text { medical instruments and equipments. }\end{array}$ & $\begin{array}{l}\text { Patients rely on private chemists for purchase of } \\
\text { hospital supplies and on private labs for investi- } \\
\text { gation services. Citizens pay higher rates to the } \\
\text { private healthcare providers for the same services. }\end{array}$ \\
\hline $\begin{array}{l}\text { Revenue income from patient care has increased } \\
\text { only marginally. Input costs for healthcare ser- } \\
\text { vices have gone up substantially. }\end{array}$ & $\begin{array}{l}\text { Pricing of hospital services is not in line with the } \\
\text { input cost of providing services and the extent of } \\
\text { subsidy AMC wishes to offer. }\end{array}$ \\
\hline $\begin{array}{l}\text { Many patients enjoy free treatments and/or get } \\
\text { additional subsidy on the already subsidized rates } \\
\text { by producing "low income certificates" signed by } \\
\text { the AMC councilors and other elected representa- } \\
\text { tives. }\end{array}$ & $\begin{array}{l}\text { Loss of revenue to AMC leads to further cuts in } \\
\text { the budgetary allocations by AMC for healthcare, } \\
\text { which means less funds for variable expenses, } \\
\text { which in turn affects the quality of service. }\end{array}$ \\
\hline $\begin{array}{l}\text { No regular allocations from AMC to the hospitals } \\
\text { for capital expenses. }\end{array}$ & $\begin{array}{l}\text { Lack of infrastructure resources forces many pa- } \\
\text { tients to depend on private labs for investigation } \\
\text { services. }\end{array}$ \\
\hline $\begin{array}{l}\text { Operating theatres and investigation departments } \\
\text { have expensive resources, used mostly during the } \\
\text { morning shift } 8 \text { AM- } 2 \text { PM, and lying idle at other } \\
\text { times, except for handling emergency cases. }\end{array}$ & $\begin{array}{l}\text { Under utilization of the resources in these de- } \\
\text { partments leads to real and opportunity losses of } \\
\text { revenue from patient care. }\end{array}$ \\
\hline $\begin{array}{l}\text { The current organizational structure is not suffi- } \\
\text { ciently sensitive and responsive to meet the needs } \\
\text { of the hospitals. }\end{array}$ & $\begin{array}{l}\text { Sanctioned posts remain unfilled for months, } \\
\text { hence recruit temporary employees. What is their } \\
\text { commitment to work and service quality? }\end{array}$ \\
\hline $\begin{array}{l}\text { AMC central medical stores follows old proc- } \\
\text { esses and procedures, and consequently its inven- } \\
\text { tory management is highly unsatisfactory. }\end{array}$ & $\begin{array}{l}\text { Inventory management of hospital supplies is } \\
\text { critical when sufficient funds are not available for } \\
\text { variable expenses. }\end{array}$ \\
\hline $\begin{array}{l}\text { Every hospital has a pharmacy store, run by third } \\
\text { parties, where prescription drugs are sold at con- } \\
\text { cessional prices. }\end{array}$ & $\begin{array}{l}\text { Frequent stock outs of prescription drugs forces } \\
\text { the patients to buy from private parties at higher } \\
\text { prices. }\end{array}$ \\
\hline $\begin{array}{l}\text { The central purchase committee of AMC still fol- } \\
\text { lows outdated and antiquated processes and pro- } \\
\text { cedures for capital purchases. }\end{array}$ & $\begin{array}{l}\text { Procedural Delays add to the concerns on the } \\
\text { quality of healthcare services. }\end{array}$ \\
\hline Very poor interaction with public. & Unreal expectations from the public. \\
\hline
\end{tabular}

Table 1: Some observations on the working of AMC hospitals 


\section{Utilization of Resources}

Operating theatres and the investigation departments consume large amount of resources and are therefore expected to generate large amount of revenue. These facilities are fully operational only during the morning shift from 8.00 a.m. to 2.00 p.m. Expensive resources in these facilities are lying idle at other times of the day, to handle only emergency cases.

\section{Central Medical Stores \& Hospital Pharmacies}

The central medical store of AMC manages the inventory of hospital supplies to all its hospitals. Sale of prescription drugs to AMC patients at subsidized rates is through hospital pharmacies located in each hospital and managed by contractors selected by AMC based on their bids to offer these services. The central medical store and the hospital pharmacies follow legacy systems and procedures in managing their inventories, and do not meet the needs of the hospital and/or the patients satisfactorily.

\section{Administrative support from AMC}

The organizational structure and the administrative support from AMC to the tertiary hospitals are not sensitive and responsive to the needs of the hospitals. Many sanctioned posts are lying vacant and AMC keeps recruiting temporary staff to fill these positions. Temporary staff, unlike the permanent staff, does not have a high degree of commitment to work, and so the quality of the hospital services suffers. Also frequent transfer of the support staff between hospitals and other AMC establishments (schools, transport department etc) affect the quality of hospital services which require trained and dedicated staffs.

\section{Interaction with the Citizens:}

Interaction between $\mathrm{AMC}$ and its citizens is very poor leading to unreal expectations from its citizens on AMC services. No information is shared by AMC with its citizens on costs and revenue for providing healthcare services at subsidized rates. As a result, there are several complaints and newspaper articles about the quality of healthcare services at AMC hospitals.

\section{e-Governance applications :G2A, G2B, and G2C}

e-Governance applications consist of one or more of the following 3 basic modules (Holmes, 2001):

G2A : Government to Administration

G2B : Government to Business

G2C : Government to Citizens

G2A applications are aimed at "putting the house in order first". This calls for inter-linking various government departments to achieve a coordinated approach to governance and thereby improve the efficiency and effectiveness of the government departments. This is the most difficult module in any e-Gov. application, as it usually involves process reengineering and change management (administration) to obliterate vertical legacy systems, process and procedures. However, we feel that the success of G2A applications determine the success of G2B and G2C services.

G2B applications achieve cost reduction for the government departments to deliver quality service to the business community. The earliest e-Governance success should come in dealing with the business community who always welcome any move to reduce red tapes and simplify their transactions with government. G2B services can lead to substantial economic development of the state. Economic benefits will be visible. 
e-Governance for Municipal Hospitals

G2C applications add values and convenience to the citizens rather than offer any financial incentives. G2C services are usually offered through a government portal which links all the government departments and agencies to deliver integrated services through a "single window". G2C applications, by their very nature, are more visible than G2A or G2B services. Citizens tend to view G2C services as a move by their governments towards better governance, and not more governance.

\section{G2A: Inter-linkages between Cost, Revenue, Subsidy, and Quality of Health- care Services}

Various AMC departments participate in the delivery of hospital services; Central Medical Store, Offices of the Dy MC (Hospitals), Dy MCs of Finance, Administration, Security, and Engineering, as well as the clinical, investigation and administrative departments in each hospital. Integration of information across these departments is necessary to provide a satisfactory level of services. It is this integration that we sought for and established to address the cost, benefit, and subsidy in healthcare services offered by AMC.

Costing of Hospital Services is a very complex process, as every service is a combination of several activities, each activity consuming a variety of resources. Traditional methods of costing do not recognize the variable levels of consumption of hospital resources for each service. Distortions thus arise in the costing of hospital services, which leads to distortions in the pricing of these services, which in turn impacts the subsidy for healthcare services. Activity Based Costing overcomes all these limitations, as it allocates costs based on the amount of each resource consumed for each service. Below we describe the procedure we have adopted to derive activity based costs for general surgical procedures (Tushar and Ramani, 2001).

The existing system at AMC hospitals groups all the general surgical procedures into two categories, namely Major and Minor procedures. Minor procedures that include dressings, suturing, biopsies, circumcision, excisions, and so on account for $50 \%$ of the total number of surgical procedures. All other procedures ranging from appendectomy to radical procedures such as pancreatectomy are classified as major surgeries. This wide range of major surgical procedures vary significantly in the amount of resources consumed, but are all priced uniformly in the traditional method of costing followed at AMC Hospitals. This method can therefore lead to large distortions in estimating the costs of different procedures within the same category as well as across different categories.

We adopt the two-stage methodology of Activity Based Costing suggested by Cooper (1988). In the first stage, the total Operating Theatre (OT) expenses are allocated to each activity in proportion to the resources consumed by each activity. In the second stage, these activity costs are allocated to each category of surgical procedures based on the amount of each activity required for each category of surgical procedures.

Our analysis is based on sample data collected from an AMC Hospital for a period of three months, MayJuly 2000. Our database consists of detailed data on activities, expenses, and the utilization of resources for each of the 626 surgical procedures carried out in the OT during the above period. Activities in an OT start with the entry of each patient in the OT complex and ends when the patient leaves OT after the surgical procedures are completed. Based on our observations and discussions with the OT staff, we have classified all the OT activities into the following five major activities:

- Preparation of OT Complex

- Pre-operative and post-operative checks on patients.

- Pre-Operative preparations of Patients in the operating rooms

- Anesthesia 
- $\quad$ Surgery

Our first task was to identify cost drivers for each activity and the measure of allocation of activity costs to each category of surgical procedures. Activity Costs are then allocated to the Category of Procedures using the allocation basis of the cost drivers, and the results are summarized in Table 2. Note that $\mathrm{ABC}$ methodology has classified all the surgical procedures into 5 categories instead of only 2 categories in the existing system.

It can be seen from Table 2 that the ABC methodology has classified 336 out of 626 procedures (54 percent) as Minor procedures, which more or less agrees with the existing classification of surgeries as Minor procedures. However, there are serious distortions in the existing system, which classifies all the remaining 290 procedures under one single category of Major procedures. The ABC method has classified these 290 procedures into 4 categories, the average cost for each category being Rs.2400, Rs.3600, Rs.4800, and Rs.7000 respectively per procedure, and thereby satisfactorily addresses the concerns on cost distortions present in the traditional method of costing hospital services.

AMC has accepted our recommendations for classifying the surgeries into 5 categories, and also announced revised prices for surgeries last year. Our recommendations for pricing of investigation services have also been accepted and implemented. These revised rates for investigation and surgical procedures were established by AMC after taking into account the costs, revenue and the subsidy for hospital services. The results are very encouraging, and the gap between the variable costs and revenue has considerably narrowed since. This application will be ported to the Wide Area Network platform (AMCWAN) as soon as soon AMCWAN is ready.

\begin{tabular}{|c|c|c|c|c|c|c|c|}
\hline $\begin{array}{l}\text { CATEGORY } \\
\text { OF SUR- } \\
\text { GERY }\end{array}$ & $\begin{array}{l}\text { COSTS FOR } \\
\text { ACTIVITY A } \\
\text { (IN RUPEES) }\end{array}$ & $\begin{array}{l}\text { COSTS FOR } \\
\text { ACTIVITY B } \\
\text { (IN RUPEES) }\end{array}$ & $\begin{array}{l}\text { COSTS FOR } \\
\text { ACTIVITY C } \\
\text { (IN RUPEES) }\end{array}$ & $\begin{array}{l}\text { COSTS FOR } \\
\text { ACTIVITY D } \\
\text { (IN RUPEES) }\end{array}$ & $\begin{array}{l}\text { COSTS FOR } \\
\text { ACTIVITY E } \\
\text { (IN RUPEES }\end{array}$ & $\begin{array}{l}\text { TOTAL } \\
\text { ACTIVITY COST } \\
\text { (IN RUPEES }\end{array}$ & $\begin{array}{l}\text { AVERAGE } \\
\text { COST } \\
\text { (IN RUPEES }\end{array}$ \\
\hline I & 42047 & 31597 & 112062 & 73412 & 113025 & 372143 & 1108 \\
\hline II & 44180 & 12225 & 43357 & 90200 & 120571 & 310533 & 2389 \\
\hline III & 37477 & 6301 & 22346 & 88511 & 90709 & 245344 & 3661 \\
\hline IV & 29860 & 4514 & 16009 & 97551 & 78026 & 225960 & 4708 \\
\hline $\mathrm{V}$ & 45704 & 4231 & 15008 & 151393 & 98736 & 315072 & 7002 \\
\hline Total & 199268 & 58868 & 208782 & 501067 & 501067 & 1469052 & ----- \\
\hline
\end{tabular}

Table 2: Allocation of Activity Costs to OT Procedure Categories

\section{G2B: Procurement at AMC Central Medical Store}

AMC has two main stores, namely, a Central Medical Store in charge of hospital supplies and a Central Store for all general items such as stationary, electrical goods, building materials etc. The Central Medical Store maintains a computer system to generate reports on stock status and vendor details. The main responsibility of the central medical store is to prepare and process the tenders for all the items, and get the necessary approvals for rate contracts from the corporation. Once the rate contracts are approved, each individual hospital is free to place orders with the approved vendors.

The existing system in each hospital woks as follows. The medical store in each hospital maintains a set of registers/ledgers to record each type of transaction - receipt of goods, issue to departments, orders placed, orders pending etc. These records are maintained mostly for audit purposes, and not for managing 
e-Governance for Municipal Hospitals

the inventory. As such, these ledgers are all prepared independently, with no integration of information across ledgers. User departments place their monthly indents to the stores by the first week of every month. Items are issued to the departments based on the availability of stocks. There is no well defined reorder policy for any item, orders are placed with the approved vendors based on the subjective assessment of the stores clerk regarding his estimates for quantity required, quantity in stock, and the lead time for various vendors. Many items are out of stock frequently due to various reasons, such as delayed delivery, and limited budget for consumables. On receipt of goods, the hospital superintendent processes the bills for payment and sends them to the Accounts \& Audit Department at AMC for actual payment to the vendors.

The existing system of inventory management of hospital supplies needed a thorough reengineering to meet the hospital requirements on patient care at minimum cost. We have recommended a reengineered material management process. The reengineered system would have only $25 \%$ of the original number of vendors, and a credit period of only 1-month instead of the existing 3 months period. By reducing the number of vendors and the credit period, AMC would enjoy $15 \%$ to $25 \%$ discounts on all purchases. At the beginning of every financial year, AMC would place an annual purchase order with all the vendors and a clear delivery schedule for each month of the year. This annual purchase order would meet 70-75 percent of the annual needs, and therefore monthly purchase orders are raised only to meet the remaining requirements. We have prototyped a reengineered materials management process described above. Results were very encouraging. An AMCWAN-enabled e-procurement system inter-linking the AMC medical store with the vendors would be implemented to achieve the projected efficiency and effectiveness in managing the inventory of hospital supplies.

A similar system for management of spare parts to minimize the downtimes of medical instruments and equipments would also be implemented on the AMCWAN.

\section{G2C Services}

G2C services can be broadly classified into two types, namely, Enquiry Services, and Service Delivery. It is much easier to provide enquiry services than service delivery. We firmly believe that the success of any $\mathrm{G} 2 \mathrm{C}$ service delivery would depend very much on the success of reengineered G2A applications to facilitate service delivery. Without reengineering the existing systems, processes, and procedures and incorporating the necessary administrative changes the reengineering efforts calls for, no G2C service delivery will be effective and efficient in the long run. Elaborate plans are underway at AMC to deliver a number of G2C services including healthcare services. Also, AMCWAN has to be successfully implemented before AMC announces any G2C services. We will focus on G2C services by AMC in a later paper.

\section{Conclusion}

In this paper we have described illustrative applications of G2A and G2B services for AMC to meet its social obligations on the health sector. G2C applications for hospital services are under planning at AMC along with other AMC services. Also under consideration by AMC are proposals to reengineer the existing organizational structure of AMC for delivering healthcare and other services.

\section{References}

Chan, Y., (1993), Improving Hospital Cost Accounting with Activity Based Costing, Health Care Management Review, Vol.18, No.1, Page 72

Douglas Holmes (2001), , Nicholas Brealey Publishing, London, e.Gov.: e-Business Strategies for Government. 
Lakhia T.S., and Ramani K.V.(2001), Hospital Logistics: Activity Based Costing For Hospital Services, of the First International Conference on Integrated Logistics, ISBN, 981-04-4562-8

\section{Biographies}

K.V. Ramani obtained his Ph.D. in operations research from Cornell University, USA in 1977. He is currently a Professor in Computers and Information Systems at the Indian Institute of Management, Ahmedabad, India. He has taught at the Johnson Graduate School of Management at Cornell University, Ithaca; Florida International University, Miami; and at the National University of Singapore. He has also been a visiting scholar at the University of Western Sydney, Macarthur, NSW, Australia; University of Texas at Austin; and the Helsinki School of Economics and Business Administration in Finland. He has published extensively in Interfaces, Journal of Strategic Information Systems, Simulation and others. His teaching and research interests are in hospital management, IT planning and implementation, computer simulation, and distance learning.

Tushar Lakhia received his MS in General Surgery from Gujarat University, India in 1978; FICS in General Surgery in 1986, and M.Phil in Hospital and Health Systems Management from Birla Institute of Technology and Science (BITS) Pilani, India in1999. He is an Honorary Professor of Surgery in NHL Medical College, Ahmedabad, India, and is also a consultant in Hospital Management. 